International Dairy Federation 1995 Milk and Milk Products. Guidance on Sampling. Brussels, Belgium: FIL-IDF Standard No. 50C

International Dairy Federation 2002 Guidelines for a Standardized Description of Microbial Inhibitor Test. Brussels, Belgium: FIL-IDF Standard No. 183, ISO/DIS 13969

International Dairy Federation 2010 Current Situation \& Compilation of Commercially Available Screening Methods for the Detection of Inhibitors/Antibiotics Residues in Milk. Brussels, Belgium: FIL- IDF Standard No. 442

Kang JH, Jin JH \& Kondo F 2005 False-Positive outcome and drug residue in milk samples over withdrawal times. Journal of Dairy Research $\mathbf{8 8} 908$ 913

Kantiani L, Farré M \& Barcelo D 2009 Analytical methodologies for the detection of $\beta$-lactam antibiotics in milk and feed samples. Trends in Analytical Chemistry 28 729-744

Le Breton MH, Savoy-Perroud MC, Diserens JM 2007 Validation and comparison of the Copan Milk Test and Delvotest SP-NT for the detection of antimicrobials in milk. Analytical Chemical Acta 586 280-283

Martínez JR, Gonzalo C, Carriedo JA \& San Primitivo F 2003 Effect of freezing on fossomatic cell counting in ewe milk. Journal of Dairy Science 86 2583-2587

Molina MP, Althaus RL, Balasch S, Torres A, Peris C \& Fernandez N 2003 Evaluation of screening test for detection of antimicrobial residues in ewe milk. Journal of Dairy Science 86 1947-1952

Navrátilova P 2009 Screening methods used for the detection of veterinary drug residue in raw cow milk- A review. Czech Journal Food Science $\mathbf{6}$ 393-401

Perme T, Bizjak M, Gacnik KS \& Kirbis A 2010 Validation of Twinsensor, screening test for the detection of beta-lactams and tetracyclines in milk, and comparison to Delvotest SP-NT. Slovenian Veterinary Research 47 97-106

Roca M, Molina MP, Villegas L, Gabirondo E \& Althaus RL 2008 Effect of cold storage on stability of tetracyclines in milk. International Dairy Federation Proceedings 1. 42 World Dairy Summit Mexico

Sánchez A, Sierra D, Luengo C, Corrales JC, Morales CT, Contreras A \& Gonzalo C 2005 Influence of storage and preservation on Fossomatic cell count and composition of goat milk. Journal of Dairy Science $\mathbf{8 8}$ 3095-3100

Schenck FJ \& Friedman SL 2000 The effect of storage at $4{ }^{\circ} \mathrm{C}$ on the stability of ampicillin residues in raw Milk. Food Additives and Contaminants $\mathbf{1 7}$ 675-677

Sierra D, Sánchez A, Contreras A, Luengo C, Corrales JC, de la Fe C, Guirao I, Morales CT \& Gonzalo C 2009a Effect of storage and preservation on total bacterial counts determined by automated flow cytometry in bulk tank goat milk. Journal of Dairy Science 92 4841-4845

Sierra D, Sánchez A, Contreras A, Luengo C, Corrales JC, Morales CT, De la Fe C, Guirao I \& Gonzalo C 2009b Detection limits of four antimicrobial residue screening tests for $\beta$-lactams in goat's milk. Journal of Dairy Science 92 3585-3591

Stead SL, Ashwin H, Richmond SF, Sharman M, Langeveld PC, Barendse JP, Stark J \& Keely BJ 2008 Evaluation and validation according to international standards of the Delvotest ${ }^{\circ}$ SP-NT screening assay for antimicrobial drugs in milk. International Dairy Journal 18 3-11

Toldrá F \& Reig M 2006 Methods for rapid detection of chemical and veterinary drug residues in animal foods. Trends in Food Science and Technology 17 482-489

\title{
Effect of storage and preservation of milk samples on the response of microbial inhibitor tests - ERRATUM
}

Milagro Borràs Llopis, Marta Roca Marugán, Rafael Lisandro Althaus and Maria Pilar Molina Pons

doi: 10.1017/S0022029913000423 Published Cambridge University Press, 9 October 2013

The name of the second author is Marta Roca Marugán and not Marugón as published.

\section{Reference}

Borràs. et al. (2013) Effect of storage and preservation of milk samples on the response of microbial inhibitor tests. Journal of Dairy Research $\mathbf{8 0} 475-484$ 